\title{
The Levant: Reconciling a Century of Contradictions
}

\author{
Mazen Hashem
}

\begin{abstract}
Although the revolution in Syria is unfolding within the country's modern political borders, what is going on can only be understood by placing it in a larger historical context, which includes the adjacent geographical areas of Bilad al-Sham. Without such a broader view, the complexity of Syria's current reality can neither be appreciated, nor can its consequences be accounted for and its future anticipated.

Probably in no country is the mess of a land's colonial legacy more visible than it is in Syria. This legacy's pathway marks the country's future development, and its implications are facing the revolution today with arduous challenges. The resulting complexity extends beyond the political dimension, for a similar level of complexity exists at the meta-cultural level as well. Furthermore, the change in Syria has regional consequences: It will institutionalize the Arab revolution as an unavoidable political force and energize the process of cultural reformation and the recovery of a civilizational Muslim identity.

This essay first examines the region's historical background and the consequences of the Ottoman order's disintegration. Second, it analyzes the national identity dilemmas faced by the Arab world after colonialism, how non-Muslims reacted to them, and the two political paths that those countries pursued. Third, the essay discusses the formation of grievances among Syrian minorities in
\end{abstract}

Mazen Hashem is a sociologist whose research currently focuses on social change and Muslim communities and institutions in the United States and around the world. He can be contacted at hashem@accis.net. 
particular. Fourth, the politics of the post-independence era are presented, highlighting the promise of the development upon which Syria was embarking. The essay then investigates the politics and social conditions that led to a dictatorship of three overlapping types: ideological left, sectarian, and neoliberal. Before focusing on the ongoing revolution, a note on Islamic activism is presented due to the fact that Islamic meanings have always been the impetus propelling the people's resistance. The revolutionary realities on the ground are then elaborated upon, emphasizing how the regime's extreme violence against peaceful protest intersects with historical social alignments. Lastly, the essay discusses the geopolitical context in which the Syrian revolution is taking place, which at once makes it hard to prevail and makes any of its outcomes highly consequential for the whole region.

\section{The Ottoman Backdrop}

Few major Old World civilizations did not cross the land known today as Syria. "Bilad al-Sham" is used in this essay instead of "Middle East," since the latter implies that the region has no character of its own but is just located in the middle between a colonizer in the West and its colonized subject in the Far East. The area points to what has "been both prize and passageway for conquerors from both the east and the west for millennia." "Today's Syria was once part of the Sassanid and Roman empires; hosted the Phoenicians of the first millennium BCE; and was the land of the third-century CE Queen Zenobia of the Palmyrene Empire, who led a famous revolt against the Roman Empire. All of them have left landmarks on Syrian soil; however, it was Islamic civilization that formed the region's soul. This is what my use of "Bilad al-Sham" is trying to denote. Indeed, for centuries Bilad al-Sham was at the heart of the Muslim order that stretched from the Atlantic Ocean to the borders of China. Damascus was the Umayyad's capital city, and Muhammad Ali of Egypt controlled this land until the Ottomans pushed back again. In modern times, Bilad al-Sham has represented the Arab gateway to the Istana, the center of the Ottoman Empire.

Contemporary Syria was both always part of something larger and, simultaneously, at the center of it. Modern Syria, with its current international borders, is a totally artificial invention. Yes, the Assyrians and other ancient populations built famous civilizations in what is today's Syria, but those were local civilizations that did not form political units with delimited borders that corresponded to natural geographical boundaries. This birthplace of many civilizations did not form a continuous political unit, similar to what we see in 
Egypt, for example. Furthermore, being at the crossroads of migration waves for centuries, Syria's population diversity means that one cannot speak of an aboriginal group.

Before the formation of modern Syria, the area was part of the Ottoman Empire. A quick examination of some major factors within that empire is highly relevant to understanding the early development of the Arab region, especially Greater Syria (and Egypt). Three Ottoman developments were specifically consequential, namely, military reform, bureaucratic reform, and reorientation of the elite's education, for they were intertwined and surely represent the top challenges of modernity. The Ottoman administration became cognizant of the rise of the European powers, who were either chipping away at some of its territories or forcing it to make previously unthinkable concessions. If the Ottoman Empire was specifically distinguished due to its administrative ability and military capacity, it is those two aspects that became visibly challenged in the late nineteenth century. While the image of stagnation is popularly assigned to the late Ottoman era, one may observe that its administrators, in fact, experimented with many types of reform. But none of them worked, probably because they were inconsistent with the empire's unique system. Thus the empire found itself in a specific bind: There was a definite need for change, yet the nature of the attempted changes conflicted with the system's operative mandates.

Two reform decrees were vital to the Arab region: the Hatt-i Sharif of Gulhane (1839) and the Islahat Fermani (1856). Such "liberal" reforms were intended to recast the Ottoman identity (osmanlilik) in a way designed to maintain the citizens' equality or, more accurately, to reshape this identity in order to accommodate the spirit of modernity. Ironically, such policies were unsatisfactory, if not inflammatory, to both the Muslim majority and the nonMuslim minorities. For example, before the reforms Christians were exempt from military service; the reform canceled this advantage and then was reinstated against a fee. As James Gelvin put it:

It is thus ironic that the policy of promising equality to all inhabitants of the empire, regardless of religious affiliation, hardened communal boundaries and precipitated instances of intercommunal violence. In the process, it created the distinctly modern phenomenon of sectarianism all too familiar to observers of the contemporary Middle East. ${ }^{2}$

Minority advantage was also structurally introduced into economic affairs. In trying to strike a balance between the global powers, the Ottomans often offered Britain and France "capitulations" to buy their support. As the Ottoman 
economic system became more integrated with the world economy, Christian merchants acted as middlemen with Europe, as did Jewish merchants, but to a lesser degree. Granted that these minorities had a linguistic advantage, but more importantly, the European consulates bestowed berats upon them. Berats were part of the capitulatory agreements that gave Ottoman citizens the advantages extended to merchants of European states in the form of lower custom duties and tax breaks. ${ }^{3}$ The advantages gained by minorities, mainly the Christians, indirectly facilitated the fragmentation of Bilad al-Sham, the house of many of those who benefited from the capitulations.

\section{Culture and the Collective Identity}

The Arab Spring and the Syrian revolution are more than just political upheavals, adjustments to the restructuring of the global economy, or the materialization of regional power realignments. To be sure, these factors do impinge upon the revolutions and represent structural constrains that both affect their shape and dictate the range of possible outcomes. Nevertheless, the Arab revolution rests upon the deep-rooted seeds in which collective identities are anchored and cultural visions are formed. I can touch on this subject only briefly, and the end of the Ottoman era is a good starting point.

The post-Ottoman era marked the Arab world's formal introduction to modernity. Modern development entered the region through social, economic, and political conditions either created or facilitated by the colonial powers. Within such a context, we can conceive of two paths of development: the sultanic and the cosmopolitan. The sultanic path was championed by locally legitimate elites who kept or constructed a pseudo-Islamic mantle of governance, while the cosmopolitan path sought modern and nationalistic anchors for their legitimacy. Morocco, Jordan, Kuwait, Saudi Arabia, the Gulf emirates, Oman, and Yemen adopted the sultanic path. Except for Morocco, these countries were not directly colonized. In fact, some of them had never before existed as separate political entities; rather, they were created in the shadow of colonial powers (specifically Britain). But not being directly colonized (Aden of Yemen was ruled by Britain) does not mean they did not develop within the new colonial world order. Morocco represents a unique case, as it was formally colonized and yet had never been part of Ottoman Empire. Other Arab countries - Mauritania, Tunisia, Libya, Egypt, Palestine, Syria, Lebanon, and Iraq - underwent a more direct form of colonization.

We can detect two patterns here. The conditions of those countries that were not directly colonized allowed traditional elites to continue leading, somewhat smoothly, while colonized countries had to construct a totally new 
political order, very much paralleled by significant social realignments. The difference between the nature of British and French colonial control here is not insignificant, for the French policy of assimilation in North Africa had major cultural consequences.

Although not true for all cases, one can say that the more intellectually vibrant countries followed the second path, that of constructing a modern state along the model of the colonial power that had seized control of their country. Generally speaking, the question of Arab national identity became salient in the post-Ottoman era. While the first path maintained a conservative national identity, posed as "Islamic," countries of the cosmopolitan path raised an overt Arab nationalist identity, anti-Ottoman and anti-Islamic in some cases, along with considerable elements of secular liberalism. Obviously, Palestine represented a special case as it was recolonized by a religio-national political order that claimed ancient historical rights to the area.

What is specifically intriguing and calls for clear explanation is that Bilad al-Sham remained this Muslim region's most diverse land. Except for Egypt, which has a 5\% Coptic Christian population, ${ }^{4}$ Arab North Africa had a near complete Muslim population (Sudan minus the south, now known as the Republic of South Sudan, is almost all Muslim). This is also the case with Turkey and Iran. The emerging picture, then, is that the traditional Muslim centers had high levels of religious diversity, whereas the population of the surrounding land was almost all Muslim.

Contemporary Syria has more than a dozen small religious and ethnic groups. However, its portrayal as a mosaic country is inaccurate and, at times, suffers from a deceptive innocence. The country is a mosaic in the sense that it hosts different living patterns in various locales. Indeed, the locals can even distinguish between the pattern of one neighborhood and another. Syrians cherish and respect such differences, and to that end we can speak of communal diversity. But this does not mean that the country has no common character and national threads - even the casual visitor cannot miss the fact that Syrian society is just as Muslim and conservative as it is modern. Syrian culture also has a distinct Mediterranean character. Speaking of linguistic groups, the majority are Arabs (90\%), while the Kurds represent the largest non-Arab minority. In terms of religion, the Sunni Arabs and Kurds form $74 \%$ of the population, while around $16 \%$ are Alawite, Druze, and others. Officially, Christians comprise 10\%; some studies, however, report only 5\% due to a high rate of emigration. If we consider Syria and Lebanon together, the share of Christians increases, whereas the $10 \%$ share of Alawites decreases. If we include Jordan, the share of Alawites declines ${ }^{5}$ while that of Christians stays the same. 
The designation "Alawite" should be taken with care. Today, this term refers to the Nusairi sect that branched off from the Seveners in the third century AH, who had, in turn, departed from the Shi' ah in the middle of the second century AH. The Shi'ah maintained the core of Islamic beliefs and practices, while the offshoot groups did not. ${ }^{6}$ In terms of theology, the Nusairi belief is a syncretistic theological amalgam of Gnostic, Christian, Muslim, and Zoroastrian elements. Yet it is not helpful to think of the Alawites as a religious group; rather, this term stands for an ethnic group that has a special folk religion. Indeed, the Nusairis did not develop an extensive theological literature and produced few prominent religious scholars due to the sect's relatively small size. More importantly, the average contemporary Alawite is not versed in religious meanings beyond what a folk religion can offer: a symbolic collective identity with minimal normative directives. Their lifestyle and the mundane conditions under which they live have become far more significant in the modern era. Nevertheless, this religious designation is a highly important marker, especially in the current conflict, even if it has little substance.

The new Arab nation-states coupled post-colonial political developments with intellectual trends as they tried to forge national identities. The idea of Arabism, which could be contrasted with Turkic nationalism, became attractive. The nationalistic Young Turks organization had its mirrors in Arab countries, especially in Greater Syria and Egypt (also Iraq). But what Arabism means is another question. Its meaning, then and now, ranges from that of a dimension within an Islamic outlook stressing the Arabs' central role in Muslim history to that of the nationalism of specific countries and the imagined communities rooted in a nation-state framework.

Syrian and Lebanese Christians, as well as immigrants from those communities who lived in Europe and the Americas, were specifically prominent in promoting Arab nationalism. This discourse, however, was riddled with irreconcilable ideas, and the outlook of an "Arab nationalism minus Islam" was destined to degenerate into a state-specific nationalism. This dilemma was sharper among the minorities, since any political arrangement larger than those fragments envisioned by the colonial power placed them in a less visible place in a Muslim ocean. Thus, different minorities attempted to construct historical aboriginal identities. If a Coptic identity has high relevance to its Christian adherents in Egypt, for Muslims a Pharaonic identity has no resonance. This is similar for a Phoenician identity in Greater Syria.

Pre-Islamic identity anchors were mainly entertained by non-Muslim groups. Even the Maronite minority of Mount Lebanon, which happily adopted an ancient claim to identity, could not disparage the religious component that went with it. Ironically, this religious component was not that of 
their assumed Phoenician ancestors, but rather a religion indigenous to the area that nevertheless has connections to the specific colonizer of Lebanon: Catholicism. Such identities are not suited to serve as a unifying identity for the region, a region that was empirically dominated by Arab human stock, Muslim rule, and Arab-Muslim culture.

Although Arab nationalist thinkers came overwhelmingly from a Christian background, the Christians' contemporary attitude toward Arabism is becoming increasingly negative. For Egypt's Copts and Lebanon's Maronites, as well as the Assyrians of Syria and Iraq, calling for an Arab identity has the potential of becoming imbued with Muslim cultural elements. Thus, it has to be rejected outright or at least inspected. The alternative anchors of the collective identities that they seek are comprised of a mixture of three elements: secular ideas and an unqualified acceptance of European modernity, state-specific local cultural traits, and a religious set of meanings and belonging (viz., a special Eastern Orthodox belonging for the Copts, a special East Roman Catholic belonging for the Maronites, and belonging to the Orthodox Church for the Assyrians. There are other religious groups, such as Armenians and Protestants).

The identity tensions of Syria's Muslim offshoot groups, such as the Alawites, the Druze, and the Isma'ilis, differed from those of the Christians. While the rejection or dislike of Muslim cultural hegemony and what came with it is shared among Christians and these offshoot Muslim groups, the former showed a clear fascination with the West while the latter exhibited a strong attraction to Arab nationalism. In the case of the Alawites, their attitude toward Arabism was intensified after France handed the northwestern region, in which significant number of Alawites lived, to Turkey. However, as secular Arab nationalism began to fade, the minorities gradually became suspicious of Arabism as it is bound to bring with it Islam, or at least Muslimness. This drove the Muslim offshoot sects to emphasize a Syrian identity, as opposed to a panArab identity, similar to what the Christians had erected.

Two notes are relevant at this point. Syrian Christians refuse the designation of "minority" on the assertion that they are land's indigenous population. Certainly, they are well integrated into the society and command an elevated position within it. As for the average Alawite or Druze, local culture, meaning a village culture and a folk religion, represent their lived experiences. Such an existence perpetuates their marginality. However, the basis of their negotiated autonomy eroded after the eclipse of the Ottoman millet system. Therefore, the Alawites, the Druze, and probably the Isma'ilis vacillated between choosing Arab nationalism and a narrower Syrian nationalism, along with a realization that any larger identification would necessarily bring with it unwanted Islamic shadows. 
Furthermore, socialism became very attractive in the post-colonial era, as was the case in many African and Latin American countries that were part of the exploited Third World. But Arab nationalism has never been able to clarify its content. As we will see, Arab Spring has repositioned Arabism within a larger Islamic context, especially as regards the Syrian revolution, because the Islamic component of national identity has been denied and violated for nearly half of a century.

The discourse of the Arab secular elite today still struggles with the region's Islamic backdrop. In the past few decades, strands within the Arab nationalist discourse have reformulated their ideas to recognize the Muslim civilizational milieu by recasting it in an Arab framework. For the majority of Syrians, who are Sunni, undermining the region's Islamic background is nothing but a betrayal of their historical identity and that of the larger Arab region with which they increasingly find common ties and sentiments. In general, the Arab revolution has made this Islamic identity more salient as people rebelled against secular regimes bent on purging such identity anchors.

\section{Grievances and Polarizations}

All politics are social at base, and Syria's current turmoil has deep social roots. Its traditional social order was experiencing tremendous stress. The role of family notables, the ulama, and the sheikhs of mosques were significantly shaken by the larger forces of colonization and modernity. The stance of nonMuslim minorities and their political preferences intensified such pressures.

Marginal groups in society usually pay the highest price when the political and economic systems come under stress, and this is exactly what happened both during and right after colonialism. Generally speaking, rural areas were in a bad shape in the early days of Syrian independence, and the modernist developmental plans of that time did not pay much attention to them. Such a situation created incentives for ambitious rural Sunnis to first hail Nasserism and then the socialism of the Ba'ath Party. But there were extra complications for other national groups, the Kurds, and the Muslim offshoot groups.

Becoming detached from the Ottoman Empire and passing through colonialism did not simply stand as a political change; rather, it represented a historical juncture at which attempts were made to change the country's whole direction and very basis. In spite of all the criticism, the millet system did allow ample space for ethnic realities to unfold. The Kurds had lived in their undisputed land for centuries, and this system enabled them to live their local culture and administer themselves. But after its eclipse, these non-Arabs found themselves in a vacuum. Their disfranchisement in Syria became more acute 
in the early 1960s after the intensification of Arab nationalism. Some of ththose who lived in northeastern Syria were denationalized, based on the claim that they were not truly Syrians but rather Iraqi Kurds who had moved to Syria. It should be noted that most ordinary Kurds share with other Arab Sunnis their religious orientation. However, in terms of a political identity, Kurds represent a classic case of nationalism: an imaginary identity and rich memories connected to a specific land. Furthermore, this represents a special case within the Syrian context since it is related to the larger issue of Kurdistan, a geographical area that stretches beyond the boundaries of Syria. Communist ideas form the core of radical Kurdish organizations, but popular sentiments revolve mainly around allegiance to the traditional leadership.

The position of the Muslim offshoot sects tells a different story. As acknowledged by many historians, Islamic civilization showed high levels of acceptance of the Other, especially the People of the Book. But the Islamic theological positions and political arrangements devised by the Muslims were less accommodative of minorities that could not be classified as People of the Book or had no extensive scriptural writings. That was especially true for groups that were considered deviant offshoots of Islam itself. The Alawites and Druze of Greater Syria fit into this ghulāt category of syncretism. The Alawites arrived in the Syrian coastal area a long time ago, while the Druze lived in a mountainous area in the country's south. Self-segregation, prejudice, and developmental plans kept them away from the prosperous urban centers. Ironically, isolating themselves was both a necessary means to maintain group identity and a source of continuous marginalization. Under the Assads, however many of them moved to Homs, Damascus, and other cities, where they were given low and mid-level governmental positions for simply belonging to the sect. This reality, along with a total disregard for relevant qualifications, heightened the conditions for conflict.

In sum, the colonial legacy and the challenges of the early post-independence years created conditions that the offshoot Muslim minorities were eager to exploit and upon which they were ready to project their grievances. We can recall that the British focused on implanting structural impediments designed to spell disaster in the future, mainly such as drawing national boundaries that were incompatible with the realities on the ground. The French focused more on disturbing the cultural basis of the colonized peoples. Both strategies were inflicted upon Syria. Indeed, the French colonial project heightened the sense of grievances among Syrian minorities and groomed some of their leaders. In 1920 the French tried to formally break up the remainder of Syria into four pieces that lasted only a few years: the State of Damascus, the State of Aleppo, the Alawite state in the coastal region, and Jabal Druze in the south. 
The Christian minorities who became economically advantaged continued their journey of success in a culture that valued entrepreneurialism, and thus their members escaped marginalization or being disliked. Unlike the Kurds of Damascus and Aleppo who were well-integrated, the Kurds of the northeast became a forgotten disadvantaged group. Although the larger population did not resent them, their basic needs were ignored. At this point, it is worth noting that one of the early Syrian presidents was a Kurd, and that the legendary Christian leader Faris al-Khori was once the prime minister of Syria. The country's internal contradictions were thus not simply ethnic or sectarian, and an awkward political formation only added to the mix of problems.

\section{Post-Independence Politics}

The Syrian Arab Republic with its current boundaries is a modern construction. Indeed, before World War II there were no independent nation-states known as Syria, Lebanon, Jordan, or Palestine. The Sykes-Picot Agreement (1916) between Britain and France created the current boundaries. The fragmentation of Bilad al-Sham, the heart of the Muslim land, is well known. Syria was truncated even further when France carved out the independent Lebanese Republic and gave the northwestern Syrian province of Iskenderun to Turkey. Both of these actions deprived the new nation-state of a coastal stretch of significant economic and strategic value. To the northeast of today's Syria, part of the historical land of Kurdistan was incorporated into Syria, while the rest was divided between Iraq, Iran, and Turkey. The area's deliberate fragmentation was further accomplished by implanting Israel between the two lungs of the traditional Muslim world's center: Egypt and Bilad al-Sham.

New political formations could very well manage the created boundaries and march toward a new future. However, this usually occurs when two conditions are satisfied: the new political formation develops the nation and raises the people's living standards, and also manages to maintain stability in the international political order. Neither of these were possible in the case of Syria. The historical summary introduced above was not one of reminiscence, but a prelude to highlight structural and cultural misalignments. It is also about a political design that left open wounds in real life, wounds that materialize at the level of economics and politics.

Saying that, there is also no doubt that half of a century of the new political arrangements imposed upon Bilad al-Sham has been long enough to sharpen specific national identities within the new countries. Furthermore, those countries were not geopolitically viable in and of themselves and thus had to create their own dependencies to survive. Obviously, these dependencies were 
formed under the purview of the European colonial powers, thereby creating a zigzag of dependencies and embedding internationally induced hostilities among old neighbors. Given this reality, it is no wonder that Syria's relationships with its new neighbors were abnormal: rivalry with Lebanon, which does not have enough bases of national sovereignty; enmity with Jordan, the British ally; competition and enmity with the more resource-rich Iraq; and the near existential threat of Israel.

The above dynamics explain Syria's bumpy political road, one that has led it into the current abyss. A new and smaller Syria won its independence from France in 1946. Of the sixty-five years since then and until the eruption of the current revolution, it has spent forty-eight years under solid dictatorship. The seventeen years of civilian government were not free of military pressure and of the influence of the more powerful regional actors: the Hashemite IraqiJordanian axis and the Egyptian-Saudi axis. Nevertheless, Syrian politics contained a large measure of rationality, and those who led the country at that time were the society's cultured cream, many of whom had been educated in the West, mostly in France.

Post-independent Syria witnessed a series of short-lived coups led by military generals. The first coup, the first one in the Arab world, is widely believed to have been a CIA-sponsored undertaking, as the new president immediately signed onto a softer position toward Israel and allowed the Iraq-based TransArabian Pipeline (Tapline) to end at a Syrian port. The coups reflected the political restlessness of Syrians at the time. The resulting regimes were relatively weak and did not have high oppressive capacities. The early Syrian political system, a modified parliamentary democracy crowned with a sophisticated constitution, also featured a respected Parliament, regular voting, and peaceful transfers of power. All of these elements inspire the current revolution.

\section{A Bourgeoning Society with an Edge}

The young independent Syria had all the marks of success. Led by learned personalities who came from prominent families drawn from the major cities (viz., Damascus, Aleppo, and Homs), the elite's aspiration for a Europeanstyle government and society, and more specifically a French style, cannot be missed. The influence of French intellectuals is still evident even today. Like many of the South's other newly independent states, the ideas of "progress" and catching up with the West were unquestionable.

Post-independence confidence caused quality institutions to emerge. Entrepreneurialism led to the growth of a relatively diversified economy. Agriculture secured the food basket of the nation and exported some fine products. 
Light industry focused on textiles, basic medicines, cement, and other basics as well as consumables. Some relatively large industrial firms offered shares to be traded publically. Skillful craftsmanship ensured near self-sufficiency in meeting practical needs, from fixing machines to tailoring durable furniture. Active trade served other needs and, more importantly, connected Syria to the rest of the world.

Development on the cultural front was specifically significant. For example, the University of Damascus quickly became a reputable educational institution that was internationally recognized for its academic rigor. The development in the arts, literature, and print media was impressive. Similar to other newly independent Arab-speaking states, Arabism loomed large in the Syrian imagination. The establishment of Israel in the heart of the ArabMuslim land also stamped the national consciousness with the sense of a colonial project that betrays the region's very identity and conspires against its essential interests. Nasserism and the idea of Arab unity inflamed the imagination of all Arabs wherever they lived.

The Syrian intelligentsia made the country a major Arab hub. The Academy for the Arabic Language, created specifically to preserve and adapt Arabic to the realities of a changing world, was formed in Damascus before its counterpart in Cairo. Syria enthusiastically sent Arab-language teachers to newly independent Algeria to counter the French effort to erase the Arabic language there. The country's mood was surely nationalistically Arab: proud, determined, and idealistic but not radical. The idealism of Syrian Arabism reached its zenith in a rare event in the history of politics: In 1958, Syria's highly respected president Shukri al-Quwatly resigned in order to form the United Arab Republic, a new state that combined Syria and Egypt, to be led by Egyptian president Gamal Abdel Nasser.

This unification was a watershed event. People cried with happiness and danced in the streets when Syria merged with Egypt. This "unity period," however, lasted less than four years. The regime was inaugurated by the suspension of all political activity. For the proud Syrians in major cities, this unity quickly turned into the imposition of Egyptian bureaucracy over the Syrian national will, along with the humiliation of its army and the intimidation of ordinary people by Egypt's security forces. It also brought the nationalization of large private enterprises, which only retarded thriving industries, and some land redistribution. All of this was done under a socialist guise and in the name of the peasants and laborers. As much as these changes were hated in major cities, they were admired in smaller towns and rural areas. This period also brought electricity and running water to some villages. Significant numbers 
of Syrians became ideologically Nasserite, which later gave birth to the Nasserite Party in Syria. Nasserism accentuated class conflict, mainly a ruralurban conflict, and paved the way for socialist ideas. Ambivalence toward Nasserism still lingers in Syria.

This picture of a vibrant post-independence middle-class society could be sharply contrasted to a different picture in small towns, villages, and rural areas. Not only did large city centers exploit the economic fragility of agriculture at the national periphery, they also did not extend to these people their due respect, for they did not fit into the new western model of a modern society that so enthused the city dwellers.

\section{Politics under Ideological Dictatorship}

The fact that Syria was able to prosper for seventeen years after its independence is rather impressive. Despite scarce natural resources, its people's entrepreneurialism managed to make the country reasonably developed. This happened even as many hands changed in politics. But political maneuverings were almost irrelevant to the ordinary people, who continued their incessant quest for a better life, something at which they were adept. This period not only witnessed competitive politics but, most important of all, a bottom line of rational governance that stands in stark contrast to political reality under the Ba'ath Party. Under the party, the logic in politics shifted from pragmatism to ideology under the slogans of Arabism and socialist principles. From day one, its members espoused a Stalinist political system that concentrated all power in the Ba'ath revolutionary movement and bureaucracy.

The Ba'ath Socialist Party captured power in a 1963 military coup by exploiting a power vacuum created by eccentric political competition. Armed with a leftist revolutionary ideology, a totalitarian system was put in place. An increasingly oppressive military regime led the country. Ba'ath and Nasserite nationalist thinkers were left with the choice of rationalizing revolutionary oppression or fleeing abroad for safety.

The Ba'ath Party considered Syria's early democratic political structure to be no more than a reflection of the interests of a privileged middle class. The party's three main intellectuals, all Sorbonne graduates, believed deeply in progress and secular Arab nationalism, a vision that they developed into a revolutionary leftist ideology. It is important to note that the party's major thinkers included Zaki al-Arsuzi (1899-1968), Michel Aflaq (1919-89), and Salah al-Din Bitar (1912-80), men who came, respectively, from an Alawite, 
Christian, and Muslim background. Although they held a common secular vision and their religious backgrounds were only nominal, these backgrounds nevertheless were important because they signified identity tensions at the micro-familial and social levels. These tensions were then reflected at the macro-national level and as regards the vision for the country.

The Marxist ideal of a comprehensive revolution reflected in Aflaq's thought, the "Lenin" of the three intellectuals, asserted "revolutionary socialism" and the "party of minority elite," both of which were necessary to counter the backward bourgeoisie structure. The party's civilian leadership readily sought the help of the military, staffed by many party members, to achieve its revolutionary goals. ${ }^{7}$ Theoretically, as stated in Article 8 of the new constitution, the Syrian political system was to be run exclusively under the party's political and social leadership. Practically, and after the leftist party went through intense infighting that included the brutal elimination of internal rivalries, the political system was increasingly run by the security forces. The single anchor of legitimacy became that of being able to suppress any dissent with a vengeance.

Although Syria did not have large industrial enterprises or vast landownership, the Ba'ath continued the path of nationalization. This resulted in a decline of agricultural vitality and a near collapse of Syrian industries after they were overstaffed with unqualified party loyalists. The Ba' ath party also went through significant internal struggles. In its second phase, the party shifted leftward in an attempt to achieve a more purely Marxist model of society. This shift was sponsored by the generals who usurped power and enforced a suffocating system of governance, one that was associated with an increased Alawite and Druze influence in the military establishment.

In general, the party's rise signaled the rise of the minorities entrenched in the military; its ascendance also helped the offshoot Muslim minorities consolidate their power. Although it controlled the state bureaucracy, backed up by specific leaders in the military, the relationship between the party and the military was not based on mutualism. Rather, it was a radical ideological drive that sought to use military power to impose what it wanted. The security forces, the new order's third leg, worked with the other two to construct a system of oppression. One could safely say that this new order's operational logic was also its "undoing." To undo the bourgeoisie economic order, its parliamentary politics, along with their cultural underpinnings, the new rulers followed a course of action that could adequately be described as systematic corruption and "uncreative destruction." 


\section{Dictatorship without Ideology}

The Ba'ath's ascendance was not simply that of an ideological group taking the country by surprise. Rather, there was social basis for such a change of course. As mentioned before, post-independence upward mobility was mainly a big city phenomenon limited to Damascus, Aleppo, and Homs. The political leadership came from these cities, while the towns and countryside continued their marginality. The socialist mantra partially appealed to segments of the population that did not have much stake in post-independence development, which followed the modernization thesis. Those attracted to socialist ideas were attracted not so much because these ideas offered a crystallized ideology, but more because of their dissatisfaction with current life chances. But one should not exaggerate this economic class dimension, since Syria at that time did not have a sharp feudal system despite the existence of a few landowning families. To a large extent, Syria was - and remains - a middle-class country. Indeed, there was another basis for discontent, one that laid the ground for the current system of dictatorship.

A particular social segment, the Alawites and the Druze, experienced a double marginality, one that was both social and economic. These offshoot Muslim groups currently comprise around $15 \%$ of the population: the Alawites represent $10 \%-12 \%$, while the Druze are around 3 percent. ${ }^{8}$ Both of these syncretic sects formed in the second century AH and espouse an esoteric approach to Islam. As they did not share with mainstream Islam what is referred to as the Five Pillars of Islam or the Six Pillars of Faith, the religious literature of the Sunnis and Shi'ahs did not consider them to be Muslim. Consequently, they did not benefit from the Ottoman millet system. Nevertheless, the early Syrian constitutions explicitly stated that the Alawites are Muslims, and President Hafez Assad (1930-2000) obtained from the Lebanese Imam Moussa al-Sadr, who disappeared during a 1978 visit to Libya, a fatwa to that effect. This confessional sectarian basis, however, did not form Syria's political system as it did in Lebanon; rather, these sects' social reality was a major factor in Syria's future development.

Many of the army's enlisted men came from these two minorities and the Isma'ilis. This trend started before independence, since France formed the Army of the Levant and actively recruited from those "war able" minorities. The trend continued after independence, as such a job was a good opportunity for those who lived in neglected and undeveloped areas. The recruits were also conscious that they were acquiring power positions in society.

Seven years after the Ba'ath Party assumed power, a new revelation became apparent. While its leaders spoke in the name of the proletariat and many 
of them came from neglected villages and towns, a more cohesive core within the party was covertly orchestrating the scene. This core, known as the "military committee," consisted of five people: Hafez Assad, Muhammad Omran, Salah Jadid, Abdul Karim Jundi, and Ahmad Mir. The first three were Alawites, while the other two were Isma'ili. This secretive committee was formed in 1960 during Syria's political merger with Egypt. Jundi allegedly committed suicide, and the leftist idealistic Omran, who once led a force to rescue the Palestinians in Jordan, was exiled to Lebanon and assassinated there. Hatoom, a Druze, was the leader of a formidable and mainly Kurdish special force, as well as a reckless defender the committee's goals; he was later killed after asserting himself. When Assad assumed power in his 1970 "corrective movement," he sent Jadid to prison to die. He soon appointed his younger brother Rif'at commander of the special force (the Saraya al-Difa'a) tasked with watching out for the regime. ${ }^{9}$

The aforementioned details show the pattern of the struggle for power in Syria: a sudden shift in power holders from social elites to those on the margins of the society, followed by the use of sectarianism to consolidate power, after which the largest non-Sunni sect (the Alawites) became very powerful. Mobilized by a sense of antagonism, they took advantage of their large numbers in the military to politically and otherwise monopolize all positions of power. Later on, Assad established a more complex basis for political power.

Since Assad was minister of defense, he worked on establishing a threepronged political order. First, he reversed the course of the previous left-leaning administration under the Ba'ath and loosened governmental restrictions on free trade. Second, conscious of American penetration into the region, he worked actively to serve the interests of the world's major players. In the 1967 war with Israel, he handed over the well-fortified strategic Golan Heights without a fight. Later in 1976, he responded to the American-European plan and entered Lebanon on their behalf to neutralize the rising Paletinian power there. The Syrian Army collaborated in the Tal al-Za 'tar massacre of the Palestinians, and Syrian forces also participated in Operation Desert Storm in Iraq in 1991. Third, Assad diversified his base of support by co-opting political aspirants and creating a shadow political opposition from the remnants of Nasserists, communists, and Arab nationalists. He also co-opted a few religious figures.

In each of these three dimensions, the Assad regime manipulated two opposing poles. On the economic front, a modest opening was coupled with an empowering of a few Alawites who had no previous economic experience along with Christian, Shi'ah, and Sunni businessmen. To balance the American influence in the area, Assad supported anti-American groups: Hamas in the Gaza Strip and Hezbollah in southern Lebanon. Furthermore, he main- 
tained decent connections with the Soviet Union and modernized some army units. Thus, Assad's newly enhanced regional position allowed him to make connections with opposing powers: Turkey and some Arabian Gulf states on one hand, and Iran on the other. On the internal front, he paralleled this diversification of his political base by assigning key positions to confidants, invariably Alawite, and other personal loyalists. Just as the pre-Assad Ba'ath period was dominated by the influence of the party and the military, the Assad phase became dominated by security forces loyal to him as well as the military, now completely controlled by a special security apparatus connected to the president.

These policies allowed Assad to build a powerful regime based on his masterful manipulation of contradictions. The system is not purely Alawite, for it rests on a wider co-opted base. Its Alawite members, however, form a dependable solid base that has no choice but to support the regime. As mentioned above, Assad did not hesitate to eliminate rivals from his own sect and even from the small circle that brought him to power. He later got rid of his brother Rif'at, who had aspired to replace him during the latter's illness by going so far as to mobilize the special regime-protecting forces under his command. The ensuing showdown threatened to destroy Damascus. Hafez Assad eventually prevailed, because he had a larger sphere of control. Not willing to weaken the ruling family's cohesiveness, he negotiated Rif'at's exile to Paris with a large sum of money from the national treasury.

In summary, this phase of the dictatorship was marked by managing the demands of the global powers along with the remnants of a socialist ideology. The sectarian Alawite dimension was used as a form of solidarity within the ruling class. The regime recruited other loyalists and beneficiaries, but the solid Alawite base remained the ultimate guarantor of power.

\section{A Neoliberal Family Dictatorship}

The system inherited by Assad's son Bashar was one of family power supported vertically by sectarian loyalties and horizontally by large financial interests. The vertical component, the common Alawites, knew that they could not get a better deal. People in the horizontal component knew that their advantage was contingent and that they would be eliminated if they blinked. In fact, some of them were eliminated because of an unwanted blink.

Several challenging factors entered the scene when Bashar came to power upon his father's death in 2000. Apart from his initial inexperience in politics, changes at the international front seemed to have overwhelmed his father's system. Some were geopolitical in nature; other were economic. 
On the international scene, the Assad regime continued what it had perfected for years: betting on multiple horses. In the 2003 invasion and occupation of Iraq, Damascus played the double role of cooperating with the Americans while supporting the insurgents. Syria was forced to withdraw from Lebanon after former prime minister Rafic Hariri was assassinated in 2005, which gave Hezbollah an unexpected boost and pushed Syria into a more dependant relationship with Iran. The major improvement in relations with Turkey was historic and solidified the regime's position. Such developments were loaded with latent contradictions. Although one might conclude that Damascus maintained or even fortified its regional position, it seems that the surrounding environment confronted the regime with opposing forces that could not be reconciled. A set of forces was pushing the country toward an Egyptian-Mubarak model, while another set was intensifying its isolation by staying very close to Iran.

On the economic front, the forces of globalism that Assad the father was trying to deflect were growing stronger. Those in positions of power, including top military generals, were very interested in riding the capitalist wave. Assad Jr. introduced some measures to liberalize the economy, even if the lion's share went first to the ruling family and its confidants. However, the dynamics of capital disturbed the non-market basis of power. This careful and modest opening of the economy - basic as it was, such as allowing the Internet to operate in Syria - boosted the young president's popularity, generated new hope, and created new beneficiaries.

This and other measures, which introduced a sense of normality into Syrian life, are the same ones that made the logic of revolution more palatable: Why should one settle for the crumbs sprinkled by the still oppressive regime? The modest living improvements, which for some segments increasingly seemed like a moving target, can be bitterly contrasted with those of a new class of financial tycoons. The impetus for a revolution was already present; indeed, Islamically spirited public protest erupted several times during the era of the dictatorship. And each time it was brutally suppressed, accompanied by the desecration of Islamic symbols and systematic revenge. All of these reactions added to the accumulated grievances lying deep in the collective memories of the majority of the population.

Therefore, we can say that Syria has specific conditions that distinguish the circumstances of its revolution from all other Arab countries. First, Syrian vibrancy was matched with agitated diversity and fissures in the collective identities of the society's different groups. Second, the post-independence developmental projects and rural-urban disparity functioned as fault lines underneath the society's very foundation. Third, the colonial design facilitated an 
abnormal rise of minority sects by allowing them to play a decisive political role via the military's coercive power. Fourth, corruption was institutionalized with a revolutionary zeal under the banner of creating a secular, socialist, and anti-imperialist society. Fifth, the country's geopolitical position put it under regional pressures from the time of its formation. The ensuing regional alliances were designed to help the party in power; whether or not they hurt the lives of ordinary people was not important. All of these factors simultaneously justify rebellion and yet make it hard to bring about any such event. But before turning to the revolution of the new millennia, the realm of Islamic activism should be described, since this is where most of the revolutionary potential dwells.

\section{Islamic Activism and Politics}

Although mainstream Muslims constitute only $75 \%$ of the Syrian population, the Islamic motif pervades the national culture. Syrian culture dearly holds onto conservative values that have religious expressions, be it among Muslims, Christians, Druze, and so on. Any discussion of Islamic movements should be put into the proper context, since Syrian society has always been at the heart of Muslim civilization. These movements are organically connected to the society and thus do not merely constitute a political phenomenon or a social fad.

We can recognize five streams of Islamic movements that are mainstays in Syria (as in other Arab countries): (1) Sufi movements, which generally shun politics; (2) the ulama, who focus on scriptural interpretations and the like and thus are apolitical. When confronted with foreign invasion, however, these two groups might become political; (3) activist ulama and shaykhs who lead "mosque movements." Despite their political quietism, preaching on social issues sometimes has political implications that take center stage during a time of social strife; (4) full Islamic movements, such as the Muslim Brotherhood, in which social change, including politics, is a staple of their discourse; and (5) eclectic independents who also seek social change but belong to no organizational structure. They also tend to form the intellectual base of the general Islamic current. For example, Mustafa al-Siba'i formed the Syrian Muslim Brotherhood after his return from Egypt's al-Azhar University. Inspired by its Egyptian counterpart, he created it out of a coalition of several Islamic organizations. This type of loose formation stamped the movement's nature and internal dynamics, which led to a major split within the Syrian Brotherhood the early 1970s.

All streams of Islamic activism faced the curtailment of their activities. General freedoms, particularly the freedom of religious activism, first came 
under pressure after Syria's unification with Egypt. The regime's enmity toward the Muslim Brotherhood spilled from Egypt into Syria due to their shared ideological orientation and ultimate goal. When the unification was dissolved and political life was revived, the Muslim Brotherhood nominated senior members to serve in Parliament. It should be noted that such participation did not sit well with many ulama, who perceived it as encroaching upon their legitimacy.

When the Ba'ath Socialist Party captured power in 1963, politics became the exclusive domain of the laborers and peasants, as the party's slogans and ideology clarified. The Ba'ath party was the sole governing party, and its members were handed not only political and administrative positions, but also positions deemed influential, such as a school principal.

There were always heated confrontations within universities between the Islamically minded students and those who were Ba'athists, Nasserites, and other nationalists of secular persuasions. After the advent of the Ba'ath, the Muslim Brotherhood was considered an illegal organization, a front group of the West, and an enemy of the regime; consequently, it went underground. Repression against political adversaries and Islamic activism in particular progressively increased, reaching its zenith in the Marxist phase of the Ba'ath party in the late 1960s. When Hafez Assad assumed power in 1970, control over religious activities was loosened in attempt to manage the Islamic current, instead of letting it grow underground. Mosque movements mushroomed and became neighborhood magnets that attracted many young people. This development corresponded with a shift in Arab-Muslim consciousness.

The post-1967 national mood after the Arab defeat with Israel delegitimized nationalist Arabist claims. The turn toward religion was not simply a phenomenon among the young people, but also a common one. Muslim activists remained very cautious and completely aware of the red lines that they could not cross - just working within the acceptable parameters of teaching the Qur'an, sirrah, and fiqh. Indeed, the new Assad regime soon began a systematic effort to "cleanse" the national curriculum of unwanted Islamic ideas and laid off many "backward" Muslim teachers. Occasional imprisonment also took place.

Once in control, the party launched a campaign to inculcate a secularsocialist and an anti-Islamic program at both the cultural and the institutional levels. In the 1970s this effort assumed a sectarian meaning, for the Alawites became entrenched in the government and used their political positions for extortion. The humiliation of citizens pervaded everyday life: at the bread line, while driving and having to yield to the rushing fancy cars of the sons of officials, or at the windows of governmental offices while doing one of the many 
frustrating bureaucratic transactions. Symbolic violence that insults ordinary Muslims flared every once in a while, such as a sacrilegious drawing in a regime-sponsored magazine or the militia of the president's brother going into the streets of Damascus and forcibly removing the women's headscarves.

Actions that blatantly offended Islamic sensibilities frequently occurred during the mandatory military service. For example, a low-ranking uneducated officer would order university graduate trainees to bring their bed sheets and wrap themselves in them as if they were making the hajj. Then, he would order them to go around the cabin and say, "Labayk, oh officer, labayk" (Here I am, oh officer, here I am). One cannot exaggerate the discontent felt by the country's majority mainstream Muslim population. As a stark example, greeting someone with "Assalam Alaikum" in a formal setting became taboo.

Furthermore, being a minority (except for the Kurds) became advantageous and associated with perks, such as being trusted to occupy key positions. In matters related to security, a minority individual (except for the Kurds) is generally not suspected and therefore less likely to be imprisoned. If he/she is imprisoned, he/she is less likely to be tortured. Conversely, the more Islamically oriented the person is, the harsher the curtailment and revenge.

As day-to-day life became more suffocating, by the late 1970s the militant discourse of a free-spirited Islamic personality, based in the city of Hamah, became more convincing. The Fighting Front (al-Talia'a al-Muqatila) was formed with a program to end the regime through violence, including the assassination of key Alawite and Ba'athist officials. President Assad himself was subject to a mysterious assassination attempt in June 1980. This militant movement managed to enlist some members of the Muslim Brotherhood and of the various mosque movements. The ensuing regime campaign against Islamic activists was carried out with a vengeance, directed principally toward the Muslim Brotherhood; however, it also reached many other young Muslim activists.

The Muslim Brotherhood leadership, lacking coherence in decision making, issued statements in support of the anti-regime actions. After a puzzling event in which several dozen Alawite recruits were shot dead in a military school, the regime issued Presidential Decree Number 49, which prescribed the death penalty for members of the Muslim Brotherhood. Many were jailed and tortured just for being considered "Islamists"; others were killed in prison. Hamah itself was bombed and brutally suppressed, thereby crushing Islamic activism and causing many Muslim activists to flee the country. The regime paraded its triumphant success over the "traitors" who had "conspired against the nation." Later on, fully confident of itself, the regime sponsored mosque courses for memorizing the Qur'an. Ironically, dismantling these Islamic 
movements allowed Muslim activists to broaden their views and get more in touch with the world. Today, they are an integral part of the current revolutionary momentum.

\section{The Revolutionary Realities on the Ground}

Those who were betting that no revolution would erupt in Syria were unaware of the extent of the grievances held by the majority of the population. On the surface, Syrians were content with trying to make the best of what was available; however, the majority population bore scars deep in their hearts and minds, scars that related to their dignity and collective identity. The current revolution is a popular communal one over which no party or ideological group can claim ownership. Yes, it was preceded with activities by some human rights activists who were calling for reform. In 2000, exploiting the new young president's assumption of power, they issued the "Damascus Declaration," thereby asserting democratic demands; a similar attempt was made in 2005. The promised reforms did not materialize; even worse, those who signed the declaration, along with other prominent intellectuals, were jailed for a long time.

Such modest activities provided a democratic framework for the revolution. From day one, the revolution adopted a mature vision of a modern and just sociopolitical order. The Syrian American Council press release on April 19, 2011 summarized its demands:

We stand in support of the legitimate demands of the Syrian people and call on President Bashar al-Assad and the Syrian government to begin immediate implementation of the desired reforms, which include:

- apply immediately and completely the decision to revoke emergency law in all its forms,

- release all political prisoners and prisoners of conscience,

- introduce clear measures to fight corruption,

- recognize political parties and the freedom of expression,

- advance social justice and the pursuit of economic prosperity and social advancement and improve public services,

- restructure the security agencies to protect constitutional rights and freedoms of citizens,

- amend the constitution to limit the presidential term of office, and

- hold accountable the perpetrators of the killing of peaceful demonstrators and bring them to justice.

We ask God to save our people and preserve their unity and inspire the president to speed up the implementation of the promises and defend dignity and freedom. ${ }^{10}$ 
Numerous similar Arabic-language public releases echoed the points above. Subsequent public statements included specific demands, such as lifting the state of emergency (in place since the Ba'ath took power in 1963) and dropping Article 8 from the constitution (states that the Ba'ath Party is the leader of the state and society).

The above characterization of the revolution is too abstract. Providing a brief description of on-the-ground developments is necessary to appreciate its momentum. In early 2011 there were several marginal protest activities: a small gathering of less than 100 people near the Libyan embassy in support of its revolution, and another one near the Ministry of the Interior. Both of these were easily dispersed by the security forces. On March 15, 2011, the official day of the revolution's start, a small demonstration was organized near the historic Umayyad Mosque, reflecting the symbol of the first Muslim rule; some of the participants were arrested. Three days later, Facebook posts called for a "Friday of Dignity" and larger demonstrations broke out in several cities.

But the revolution went full blown on the day when people learned what had happened to children in the southern town of Dar'a. These children had written on the walls slogans echoing the Egyptian Tahrir Square chants: "People want to bring down the regime." Public anger erupted as the town's elders attempted to secure the release of the children who had been imprisoned by the regime for a week. Instead, its inhabitants and all Syrians were shocked to learn that these children, none over fifteen years old, were being tortured. Dara became "the cradle of the revolution," and sustained protest ensued. The security forces responded with mass arrests and live ammunition. In addition to destroying property, its tanks shelled the historic Umar mosque and its members desecrated its copies of the Qur'an.

The above synopsis is important for three reasons: (1) it asserts the revolution's relatively spontaneous nature and sudden eruption, which early on went beyond what anyone envisioned; (2) it reminds us that this peaceful revolution was met with extreme violence from day one; and (3) it highlights the security forces' intentional insulting of the public's Islamic sentiments. These dimensions continue to form the revolution's contours, despite new developments, and largely affect how it sees itself.

Within two weeks, protest demonstrations had spread to many Syrian cities; bare chests faced live bullets, and death was accepted as the price of crying out what had become the standard motto: "Allah, Syria, Freedom, and nothing else" (it rhymes in Arabic). All such incidents provoked no official response, as if nothing was happening in the country. Worse, at the end of March 2011 President Bashar addressed the nation. In place of the expected 
reconciliatory gestures, his empty speech and short involuntary laughter further offended the nation. Every revolution has a point of no return, and this early date was the first one. But a more solid point of no return occurred during the fourth month of the revolution after Homs became "the Capital of the Revolution." The following month, Ramadan, permanently stamped the revolution's character with a deep Islamic spirit, for the regime violated the month's sanctity by carrying out unspeakable acts of violence during it.

The people's revolutionary consciousness developed in three phases. The first phase was that of an innocent belief in civil action. Inspired, or more accurately duped, by the theatrical Tahrir Square view, young Syrians sought to prove their yearning for freedom and their willingness to pay the necessary price. This consciousness was captured by three YouTube segments in the early days of the revolution: a man in Dar'a faced a line of soldiers and shouted: "Kill me! Kill me!" while his friend taped the event. A young man in the suburb of Damascus, probably under twenty, ran into the middle of the street, his chest bare, and shouted "Allahu Akbar" while security forces were shooting to disperse the crowd; they shot him dead. A group of teenagers in the coastal city of Banias lay on the ground in front of tanks. This phase, which lasted for around seven months, highlighted the conviction that a solid will for freedom would awaken the world's democratic sensibilities and the revolution would somehow triumph. This phase insisted on three no's: no violence; no sectarianism, and no external military intervention.

The second phase began as the regime's continuous use of extreme violence transformed this revolutionary consciousness into calls for outside help. This phase was not only marked by violent crackdowns on street protests, but also by the appalling torture of those who were rounded up and imprisoned. The title of a Human Rights Watch report depicts the situation: "We've Never Seen Such Horror." 11 Other reports confirmed the ugly picture of systematic violence. ${ }^{12}$ After the fall of Libyan dictator Muammar Qaddafi in October 2011, people reasoned that the Libyan scenario was not so bad after all; they accepted the need to endure such pain for a clear-cut outcome. The demonstrators now started to carry signs asking for international intervention.

The third phase was that of a deep and painful realization: no international power was interested in helping the poor Syrian people. Turkish flags were once hung in some cities after Prime Minister Erdogan made some supportive statements; however, a puzzled disappointment replaced any hope of help from Syria's powerful Muslim neighbor. The reserved and wavering statements of western leaders were further disappointments. The revolutionary consciousness then validated its original doubt: It is not in the interest of any country, Arab or non-Arab, to see political change in Syria. This state of con- 
sciousness was reflected in the songs sung by the demonstrators who mocked the international powers with the oft-repeated chant: "We have nobody [on our side] but You, Oh Allah."

This last phase coincided with a serious new development: the rise of the Free Syrian Army (FSA). Defection from the official army occurred spontaneously. Homs, the central city, became the hub of protest activities. Huge demonstrations and revolutionary celebrations continually took place in its main square. The protestors' wit and creativity went beyond what the regime could tolerate, as did the neighboring town of Rastan when it toppled a huge statue of Assad the father. The army was sent to suppress the protest activities. But as many men from Rastan were in that army, they wondered how they could shoot at their own people on behalf of a regime that they loathe. Moreover, in the last decade Homs had witnessed the increased number of Alawites who were moving to and settling in its outskirts. Recruits from those neighborhoods were organized by the regime to suppress revolutionary activities.

As elsewhere in the country, similar civilian thug formations perpetuated horrendous atrocities. Not only did they break into homes, damage the contents and steal valuable items, they also used rape as the ultimate tool of humiliation. In addition, these groups were responsible for the massacres, both the slaughters and the burned families, that have recently come to light. These regime-organized rings of civilian thugs served two purposes: they intimidated and inflicted considerable damage. They also incited sectarian feelings, because probably half of their members were Alawites while the other half were non-Alawites and included released criminals and street hooligans.

Thus the FSA adopted a defensive posture to "protect civilians." Although its ranks have increased significantly over the last couple of months, its units still function independently. There are also other armed groups not affiliated with the FSA. While the early armed members were initially military servicemen who had defected from the army, they are now primarily civilians who, in the face of the regime's atrocities, have decided to carry arms to defend their honor and protect their homes. As expected, these volunteers tend to be Islamically oriented. It must be said that the armed resistance is poorly equipped and depends on what it can capture or buy. As of yet, there is no evidence of any regular external source(s) of supply. ${ }^{13}$

The situation on the ground can be summarized as follows. The regime is using the suppression tactics of an occupying army: bombing and destroying the homes and neighborhoods of many cities, towns, and villages. Ironically, from day one it struck its own social base and continues to do so. In particular, the regime feared that border cities could create a Benghazi situation, where resistance would galvanize, become a hub for defectors, and gain international 
support. Otherwise, it assumed that losing the support of peripheral areas was not crucial for its survival. Parallel to that, it was keen to suppress even the smallest protest activities in sensitive places and thus inserted considerable numbers of security personnel into Damascus (the capital) and Aleppo (the financial center).

But now even the rural areas surrounding Aleppo are up in arms. The suburbs of Damascus were active from the early days of the revolution and have remained so. For example, fifteen kilometers away from the presidential palace thousands continue to demonstrate, even though they have been repeatedly - and brutally - suppressed. Its neighborhoods also experienced creative civil protest tactics: hanging the independence flag, which is different from the current flag, on bridges; renaming streets after martyrs; and pouring red dye into the water of public fountains. Such activities are specifically inspired by Jawdat Saeed, a Gandhi-like Islamic thinker who has followers in Damascus, and by some other informal civic organizations. It is worth mentioning that such benign activities could carry a high price, namely, severe beating, imprisonment under harsh conditions, or even death under torture. While mobilization in the capital is assumed to be harder than it is in Aleppo, the former city is blessed with a few shaykhs who early on validated the idea of resistance, as compared to the dominance of Sufi shaykhs in Aleppo, who dampened it for a while.

The above description is meant to emphasize the collapse of the regime's legitimacy, the still widespread peaceful protests, and Damascus' inability to control it via extreme violence, which only breeds more defiance. The regime's logic is to raise the cost of resistance to an unbearable level; the resistance's logic is that atrocities and humiliation have reached a point that human beings who value their dignity can no longer accept. Scaling back after such huge sacrifices would mean surrender to the point of slavery. Furthermore, the regime would surely continue its suppression to the last living activist.

While rejection of the regime is widespread, the map of active resistance shows clear differences among the population. Among all groups, the intelligentsia wholly opposes the regime, despite its members' lack of agreement on how to proceed. But when we speak of communities, the picture is complex and mixed. The smallest major group, the Druze, strongly leans toward the regime despite the fact that its old friendship with the Alawites has long been replaced by enmity since key Druze figures were eliminated from powerful positions. The Christian community, whose members are most enthused with the hope of a secular democratic society, still largely support the regime; however, they are following the national struggle from a distance. There are protest activities among the northern Kurds, but they are also fighting a parallel battle 
that is equally related to the dream of an independent Kurdistan. As expected, the Alawites are behind the regime, although their intellectuals and other notable activists are anti-regime and on the side political change.

This picture explains why the revolution is sometimes referred to as an "Arab-Sunni" revolution (65\%-70\% of the population), even though there are Sunnis who still support the regime. In terms of social class, the large financial interests are partners with the regime, whereas the poor cannot afford to join the revolution. Realizing this, Damascus has tried to enlist some of them in the local thug forces. Otherwise, the revolution encompasses most social classes. In particular, university graduates hold the leadership of the neighborhoods through "coordination committees" that decide on protest activities; their places and type, signs and slogans; as well as the level of risk that should be taken.

Funding comes from a wide sector of sympathizers and well-off people, who otherwise appear to be inactive, along with already established networks of Islamic charitable organizations in the large cities. In addition, expatriates are contributing to charitable causes. Expatriates play another important role: they have formed the Syrian National Council (SNC) to further the revolution's cause on the international level. Nationalists, liberalists, leftists, and Islamists have sat down together and worked through their political differences for the first time since 1963. The SNC's popularity has declined, however, due to the unrealistic expectations of what it can achieve and due to its own failings. For example, the SNC was generally slow in developing plans, its website contained no relevant material for months, members had public relations problems with the revolutionaries on the ground, and the statements of its key members were sometimes not professional enough.

The revolutionary struggle on the ground juxtaposes the struggle of collective identities in Syria. Identity tensions are naturally stronger among minorities; and I am speaking here of collective identities, not personal ones identities in the sociohistorical sense of imagined communities. One must not forget that the Alawites are engulfed with this challenge even more than the Sunnis are. The difference is that the path of identity recovery for the Sunnis is clear, precisely because they have always formed the overwhelming majority and, more importantly, because their meta-culture forms the content of the region's civilization. In contrast, the path of identity reconstruction for the Alawites is blurry and requires many fundamental adjustments.

All collective identities pass through a stage of tension at historical junctures, and the Alawites' collective identity is now facing acute tension. Memories of past grievances do not provide enough basis for new beginnings, and anyway they are not healthy starting points. Regardless of whether their griev- 
ances were exaggerated or not, their political rise did not resolve their marginality. It is true that, unlike in the past, there are now successful Alawites those few who have worked hard and are proud of their achievements. But this is not the story of the average Alawite. The middle-class Alawites given positions in the bureaucracy are not really in a good shape, as most of them stayed within the confines of being lucky for receiving an entitlement.

The rise of the Alawite political elite actually harmed the largest segment of the poor villagers and the low-level army and security force recruits. They were neither encouraged to develop marketable skills nor to function in an environment that fosters becoming cultured. Ironically, the Alawite-controlled regime did not really serve the cause of its people. But the sect cannot imagine an order in which its members do not have a relative advantage. Furthermore, they are afraid of losing jobs and, although inconceivable, they fear that the previous owners will seek to reclaim the confiscated rural land and residential lots around the cities in which many of them live.

In such a configuration of an ethnic group, what are the options for a renewed collective identity? As expected, the Alawite financial elite has merged into the global thievery class, while the Alawite cultural elite found its nirvana in secular ideas, whether leftist or liberal. But these identity substitutes embraced by selected individuals cannot create a "real" identity for the Alawites as a totality. The collective identity then becomes prone to degenerate into a mere sticking together. Unfortunately, in their case the necessary glue was provided by an illegitimate political body that operated according to a slashand-burn formula. Thus, the Alawites who least benefited from the sectarian order are now its ardent defenders. Furthermore, some of them were led to engage in horrifying acts of violence; even some of their middle-class members participated in the orgy of violence, turning hospitals and clinics into places of sadistic acts. Unfortunately, this is far from being an unknown phenomenon in humanity's history.

Some Sunni and other non-Alawite individuals have also supported the regime, mostly by being silent and helping to normalize the revolutionary atmosphere. But those non-Alawite groups will be remembered as such - as people whose actions provided latent support to the regime. Precisely because their actions were driven by utilitarian, not sectarian, motives, they will be shunned; this will be considered a fair "punishment" for their non-action. Silent Christians might be remembered as selfish, and silent Sunnis as opportunists and timid people. The Alawites, however, cannot be remembered as such even if some of them were fencesitters. Rather, they will be remembered as part of a sect of traitors who wholeheartedly supported a criminal regime. 
Again, for Sunnis the identity challenge is a matter of recovery, of bringing alive an imagined community that, nevertheless, existed empirically and stamped the character of a civilization. The Alawites do not have such a luxury in identity construction. They seem to have three options: (1) build an identity around the religious ideas of their past; such a trend exists among some Turkish Alevis but is a rarity among Syrian Alawites; (2) draw on Shi'ism; Iran's religious establishment has been trying to facilitate this through missionary activities; and (3) opt out of any religious identity whatsoever. This seems to be their preferred choice, and the consumerism of the contemporary world certainly pushes them in that direction.

\section{Geopolitics and Pathways}

The Tunisian revolution occurred in a peripheral country that enjoys an excellent educational system and is endowed with a mature Islamic movement led by the wisdom of the popular Rashid al-Ghannushi. The Egyptian revolution came in installments and is still unfolding. The country has a significant number of civil society institutions, as well as the very influential and widespread Muslim Brotherhood. Whatever one might say about the erratic politics of this movement, it nevertheless has the potential for mass mobilization. The Libyan revolution toppled an eccentric dictatorial system that had a weak institutional basis. All of these revolutions occurred in countries with reasonably homogeneous populations. The tribal affiliations in Libya operated mainly on the social level, while in Yemen both the regime and the opposition had tribal affiliations that mitigated political power. None of these conditions are present in Syria. In comparison with other Arab revolutions, the Syrian one is far more complex and, since its outcome will have a regional impact, the obstacles confronting it continue to multiply.

After fourteen months, the situation in Syria has reached a dangerous stalemate. The regime is still cohesive at top. As Theda Skocpol theorized, "all regimes unravel from above." 14 Not only does the regime not show any cracks at the top, its cohesiveness extends downward through the Alawite network that is solidly behind it. Also, the regime depends mainly on the army's Fourth Battalion, which is well-trained, equipped, and staffed overwhelmingly with loyal Alawites. On the other hand, however, the regime is also exhausted. The latest International Crisis Group report summarized the situation:

The regime cannot truly "win"; what it might do is endure. ... Slowly but surely, its military capacity is eroding, a result of a trickling stream of defections, declining recruitment and plummeting morale. The economy is 
devastated and will remain so for the foreseeable future. In particular, the agricultural sector has been disrupted by conflict, fuel shortages and the disappearance of state services. ${ }^{15}$

The Syrian opposition is now begging for help. The strongest encouragement so far comes from Qatar and Saudi Arabia. American and European support is wavering and is limited to diplomatic and economic measures. Russia and China have been using their veto power to defeat any strong Security Council resolution. These vetoes are coming as a relief to NATO countries that are not in a position to do anything serious. One analyst has described the American position in the following terms: "Through masterful inaction we'll get the exact same result we would have through some kind of intervention."16 One might say that the international community is interested in curbing the rouge regime's power or getting rid of it, but is neither willing to pay the price nor ready to bear the consequences of achieving that goal.

The Syrian revolution is a geopolitical earthquake on a fault line at which the north-south alliance (Turkey through Saudi Arabia) intersects with an eastwest alliance (Iran-Iraq-Lebanon). If the regime collapses, there will be an instantaneous change in the political alignments in Lebanon; Iran-supported Hezbollah would lose and the Christian, Sunni, and other groups would recover their place. Jordan would likely begin switching to a constitutional monarchy; as one observer put it, it is hard to guess what Jordan would look like the day after regime change occurs in Syria. ${ }^{17}$ This means that the Arab Spring would have reached the northern borders of the Arabian Peninsula. In Iraq, the northwest Sunni region would start to recover its lost position. It is also likely that Iran's loss of its Arab ally would reawaken the Iranian opposition, which is now in disarray. It should be mentioned that Hamas had to leave its offices in Damascus, lest it be accused of siding with a regime that is trying to eradicate an Islamically spirited social movement. Again, no country in the historic Bilad al-Sham region can shield itself from the effects of the Syrian uprising.

All of the above might be dwarfed, however, by the Turkish dilemma. Turkey stands to be the top beneficiary of change in Syria, contrasted to an equal loss to Iran. Turkey has excess potential ready to flow into Syria and to cross to the rest of the Arab-speaking world. Despite the Syrian revolutionaries' bitter feelings that Turkey has abandoned them, it is nevertheless a fact that no country has more credentials in Syria. But Turkey's stance is polarized between lovers and loathers. While Syria's 70\% Arab-Sunnis see the Turkish model as their very own, the $10 \%$ Kurds are Turkey's political enemies and the remaining $20 \%$ resent it on religio-cultural grounds. Nevertheless, most of the revolutionary weight comes from the large Arab-Sunni segment. Among the political op- 
position, only small segments of the left and the Arab nationalists did not side with the regime; they are also allergic to Turkey's influence.

Turkey and Syria share similar population groupings: Around 20\% of Turkey's people are Kurds and another approximately 10\% are Alevis. Although the Alevis differ somewhat from the Alawites, they are not hiding their support of the Assad regime. ${ }^{18}$ The Kurdish issue is overwhelming for Ankara, as the Kurds' grievances are institutionally elaborated and their political power is mobilized. If Turkey helps to bring about regime change in Syria, a power vacuum will most likely occur, at least for a short period, and the Kurds would quickly exploit it to come closer to their dream of establishing an independent Kurdistan. The Syrian regime has already empowered the radical Kurdistan Workers Party and is using its forces to suppress rebellion in the northeast.

Ankara's new principle of "zero problem neighborhood," which rightly rejects the Hobbesian view of international relations, is laudable. But along with all other such principles, it has own limitations. For example, it could not be maintained or defended if we adopt a system view of geopolitical dynamics. Furthermore, while Turkey would be happy to undercut Russian and Iranian dominance, it is an energy-deprived country that must import threequarters of its energy supplies from exactly those two countries or find substitutes. Moreover, any intervention would very likely trigger revenge from Iran. While radical Iran can call for future martyrs in order to extend its political cause, rational Turkish politics, which rests on the voters' fluctuating moods swings, cannot engage in radical actions. Furthermore, an Israel that is afraid of Iran and jealous of Turkey might find that its own best interest lies in facilitating a clash between these two regional giants.

Turkey recognizes that direct interference in Syria would mean stepping into a quagmire. That is why it will not interfere in the absence of a larger coalition of international powers, and, most importantly, the United States. Currently, overly cautious Turkey has sealed its borders with Syria and only allows refugees to cross north toward safety. But the big question is whether it can remain isolated from extended turbulence in Syria.

Iran, and by extension Hezbollah, had the choice of supporting the oppressed Syria's mustad 'afin or succumbing to the ruthlessness of expediency. They chose the latter. Ironically, although supporting the revolution would entail a delicate engagement, it would have been closer to achieving the dream of a Persian empire imbued by Shi'ism. It seems that sectarian calculation blinded Tehran's usual shrewd policymaking. It put all of its weight behind Damascus only to lose its credentials in Syria and in the Arab world in general. Politicking took a sharper turn when Nasrallah, the leader of Hezbollah, pro- 
claimed to a large audience that the destruction displayed in Homs via television and YouTube was no more than a "fabrication" and warned against sympathizing with falsity. Only a few months ago his pictures were hanging in many Syrian places. The party of southern Lebanon lost a historic opportunity to normalize its existence in Lebanon and the Arab region, as well as to prove through action that it is not an Iranian front organization.

It seems that international analysts are reaching their conclusions rather late due to their underestimation of the Syrian revolution's deep-seated dynamics. If no extensive help reaches the opposition, most likely the situation will worsen and become more unstable. This would not, however, extinguish the revolution. In that case, large numbers of foreign fighters would probably pour in to join the few already there, ${ }^{19}$ thereby destabilizing the country as well as western Iraq and Jordan. ${ }^{20}$ If such forces weaken the Syrian regime, one expects that Damascus will lose control over the northeast, which would trigger Kurdish dynamics across the region, including Turkey. Protracted conflict among proxy groups fighting on behalf of regional powers, not civil war, is another possible scenario. Not only would Turkey lose an opportunity to mold the change according to its own interests, but its international stature would also suffer, thereby emboldening Tehran to bully Ankara and chip away at its standing.

Uncertainty is the most appropriate description of the current situation. The revolution's clear success would result in significantly strengthened ties among Arab-speaking countries. Along with a Turkish windfall, this means that the region's precolonial configuration is being slowly recovered. Expectedly, both Israel and Iran are keen that such a development does not materialize. Ironically, the obsessive fear of an Arab-Muslim rise might produce the very result that the status quo is trying to suppress. Furthermore, if Egypt manages to reasonably recover and Syria does not plunge into divisiveness, a new paradigm in the relationship with Europe becomes necessary, for the idea of an Arab-European Mediterranean partnership nations become feasible, if not necessary.

Two extraordinary events would dramatically alter the Syrian arena in an unexpected way. First, as the Iraqi Shi' ah polity is actively monopolizingpower, the Sunnis who once were ardent defenders of a centralized governance system in Baghdad shifted their position toward that of federalism. If the winds of autonomy become strengthened there, the formation of an autonomous Sunni province along with a more independent Iraqi Kurdistan will spill over into Syria, which would force Turkey to get far more involved in Syria than it is currently willing to do. The other dramatic event relates to the Palestinian issue. As much as it seems a farfetched possibility, an Arab Spring there is not 
out of question because the deep-seated conditions that underlie the Arab Spring in other countries are present in the Palestinian case. In fact, it can be argued that such conditions have been there for a long time. Moreover, the cumulative effect of the Arab revolutionary momentum might have a multiplier effect. There is a geopolitical torque force here. Any change in the nature of the Palestinian resistance or of ignoring Syria until its revolutionary blood spreads to surrounding lands would make resolving the Syrian crisis an international priority.

\section{Conclusion}

Syria today is reconciling the twentieth century's contradictions and the colonial heritage of the historic Bilad al-Sham. Regardless of the outcome, its revolution has already attained goals that were previously thought to be impossible to reach. The Syrian people rediscovered their collective identity as a colorful social order that is at once Muslim, Arab, and accommodative to non-Muslims, non-Arabs, and Muslim offshoot groups. In addition, the revolution has opened the Syrians' eyes to national challenges that they are eager to address and not to brush aside; unleashed social powers that no one expected to become mobilized; built bridges between rural and urban Syria in a manner unmanageable before; strengthened connections among social classes; recovered a suppressed Muslim cultural milieu, the absence of which had made people live as aliens in their own country; constructed a national vision of what the future State of Syria should look like; and, finally, connected the Syrian people more tightly with the other peoples of the Spring that has blossomed among the Arabs. Whether such achievements will become institutionalized in a new political order or not is still uncertain.

\section{Endnotes}

1. James L. Gelvin, The Modern Middle East: A History (London: Oxford University Press, 2005), 15.

2. Ibid., 82.

3. Ibid., 97-98.

4. According to Pew Global Survey, only 5\% of Egyptians are not Muslim. This is a touchy issue, as the Copts were never happy with the once-accepted population figure of 13 percent.

5. Reports note that 300,000 Arab Alawites live in the Iskenderun Turkish area, in addition to other Turkic Alevis.

6. Cyril Glassé, The Concise Encyclopedia of Islam (San Francisco: Harper and Row, 1989). 
7. Bashir Abdeen, The Military and Politics in Syria, 1918-2000 (Damascus: Dar al-Jabya, 2000).

8. See CIA World Factbook, "Syria," www.cia.gov/library/publications/the-worldfactbook.

9. Patrick Seale, Asad: The Struggle for the Middle East (Berkeley: The University of California Press, 1991).

10. See the Syrian American Council's website at www.sacouncil.com.

11. "We've Never Seen Such Horror: Crimes against Humanity by Syrian Security Forces," Human Rights Watch, June 2011, www.hrw.org/reports/2011/06/01/weve-never-seen-such-horror-0.

12. "The Long Reach of the Mukhabarat: Violence and Harassment against Syrians Abroad and Their Relatives Back Home," Amnesty International, October 2011; "I Wanted to Die: Syrian Torture Survivors Speak Out," Amnesty International, 2012, www.amnestyusa.org/research/reports/i-wanted-to-die-syria-s-torture-survivors-speak-out.

13. "Syrian Armed Opposition," Middle East Security Report, February 2012, www.understandingwar.org/report/syrias-armed-opposition.

14. Theda Skocpol, States and Social Revolutions: A Comparative Analysis of France, Russia, and China (Cambridge, NY: Cambridge University Press, 1979).

15. Syria's Phase of Radicalisation," International Crisis Group, April 10, 2012, www.crisisgroup.org/en/regions/middle-east-north-africa/egypt-syrialebanon/syria/b033-syrias-phase-of-radicalisation.aspx.

16. "Iran and Syria: A Tale of Two Crises," Brookings Institute, Saban Center, February, 2, 2012, www.brookings.edu/events/2012/0202 iran_syria.aspx.

17. See "Jordan's Reluctance to Confront Syria," Stratfor Global Intelligence, April 13, 2012.

18. “The Syrian Nightmare," Zaman Online Magazine, April 10, 2012. www.todayszaman.com/columnist-277034-the-syrian-nightmare.html.

19. "Syrian Armed Opposition."

20. See “The Long Insurgency in Syria." Stratfor Global Intelligence, April 3, 2012, www.stratfor.com/sample/geopolitical-diary/long-insurgency-syria. 